\title{
Cockroaches (Insecta, Blattodea) from caves of Polillo Island (Philippines), with description of a new species
}

\author{
Cristian C. Lucañas', Ireneo L. Lit, Jr. ${ }^{1,2}$ \\ I Entomology Section, Museum of Natural History (MNH), University of the Philippines Los Baños (UPLB), \\ College, Laguna 2 Environmental Biology Division, Institute of Biological Sciences (IBS), College of Arts and \\ Sciences (CAS) UPLB
}

Corresponding author: Cristian C. Lucañas (cclucanas@up.edu.ph)

Academic editor: O. Moldovan | Received 11 July 2016 | Accepted 9 September 2016 | Published 28 September 2016

http://zoobank.org/D138B13C-7B37-4F97-BFF7-28D170ECA543

Citation: Lucańas CC, Lit IL Jr. (2016) Cockroaches (Insecta, Blattodea) from caves of Polillo Island (Philippines), with description of a new species. Subterranean Biology 19: 51-64. doi: 10.3897/subtbiol.19.9804

\begin{abstract}
Cockroaches collected during a protracted series of fieldwork in several limestone caves in Polillo Island, Philippines were taxonomically studied. A new species of Nocticola (Nocticolidae), N. gonzalezi Lucañas \& Lit, sp. n., is described. The male of Periplaneta banksi Hanitsch (Blattidae) is described for the first time. Altogether, the present cave cockroach fauna of the island consists of six species.
\end{abstract}

\section{Keywords}

Blaberidae, Blattidae, Burdeos, cave cockroaches, Ectobiidae, Nocticolidae, troglobiont

\section{Introduction}

Cockroaches are well represented in cave ecosystems. They are classified as: trogloxene, troglophile, guanobyte or troglobiont depending on their specialization or adaptation to the cave environment (Chopard 1936, Roth and Willis 1960). Juberthie (2000) estimated that there are at least 31 species of troglobiont or obligate cavernicolous cockroaches worldwide but additional species are still waiting to be described.

Unfortunately, very few studies have been conducted regarding the diversity of Philippine cockroaches, maybe because the group includes species that are considered 
household pests. Thus, limited information is available on the country's fauna, especially in cave ecosystems. In recent years, the increasing interest in cave studies in the country has provided an opportunity to study the diversity of cockroaches in Philippine limestone caves.

The first documented troglobiont cockroaches in the Philippines were species of Nocticolidae from Rizal Province (Bolivar 1982), a few kilometers to the east of what is now Metro Manila. These were: Nocticola simoni Bolívar, 1892 (from a cave in San Mateo town), and Nocticola caeca Bolívar, 1892 (from Cueva de Talbac, in what is now Antipolo City). Roth (1988) also noted an unidentified Nocticola nymph from a cave in Montalban town (now called Rodriguez), also in Rizal Province, deposited in the Natural History Museum, Geneva, Switzerland.

Unfortunately, due to the limited knowledge on Philippine cockroach diversity, many species have often been misidentified. Encinares and Lit (2014) listed species found in caves in Polillo, including what they initially identified as Cryptocercidae sp. and Blattidae spp. 1, 2, 3 and 4. Lucañas et al. (2015) later clarified their identities to be Pycnoscelus striatus (Kirby, 1903) and Hemithyrsocera sp.

Mag-usara and Nuñeza (2014) reported Polyzosteria limbata Burmeister, 1838, Calolampra irrorata (Fabricius, 1775), Methana marginalis (Saussure, 1864) and Ellipsidion sp. from several caves in Siargao, Surigao del Norte. Although, we were not able to examine the specimens, it is likely that those cockroaches have been misidentified as the mentioned species are all restricted to Australia. Similarly, Polyzosteria and Eublaberus sp. have been reported from a cave in Lanao del Norte (Macud and Nuñeza 2014, Sobrepeña and Nuñeza 2014), which are known only from Australia and the neotropics, respectively.

Other than those, there have been very few studies regarding the diversity of cockroaches in caves. This paper provides a list of cockroaches collected from several caves in Polillo Island, Quezon Province in the Philippines.

\section{Materials and methods}

All examined specimens were either pinned (for larger specimens) or preserved in vials of $95 \%$ ethyl alcohol, unless otherwise indicated as mounted on slide using Canada Balsam. Slide preparations were made starting with cold maceration by soaking in $10 \%$ aqueous Potassium Hydroxide (KOH) solution for 24 hours at ambient room temperature. They were then washed in distilled water to remove unwanted undissolved internal contents, and then run through graded alcohol series and then anhydrous clove oil to remove excess ethanol. Finally, they were mounted on microscope slides using Canada Balsam. The following parameters were measured using a calibration micrometer for pinned specimens and calibrated ocular micrometer for slide mounted specimens:

TL (Total length) the length from the tip of the vertex (if exposed) or pronotum up to the tip of the tegmina at rest; 
BL (Body length) the length from the tip of the vertex (if exposed) or pronotum up to the tip of the subgenital plate (in case of brachypterous/micropterous/ apterous species, total length = body length);

Pn Pronotum length $\times$ width along the longest axis;

Tg Tegmina length along the longest axis.

Standard deviations for each measurement were also noted. Terminologies used for male genitalia follow Klass (1977), and Roth (2003) for other characters such as fore femoral armaments (Type A (robust spines terminating to 2-3 terminal spines), B (several proximal spines followed by row of smaller spinules with 2-3 terminal spines) and $\mathrm{C}$ (row of piliform spinules with 1-2 terminal spines).

Illustrations were made by tracing printed photomicrographs of clear slide-mounted specimens. The degree of sclerotization and pigmentation was made through line thickness and by stippling. All specimens are deposited in the Entomological Collection of the UPLB-MNH.

\section{Taxonomy}

\section{Family Nocticolidae Bolívar, 1892 \\ Genus Nocticola Bolívar, 1892}

\section{Nocticola gonzalezi Lucańas \& Lit, sp. n.}

http://zoobank.org/7E3D0AEF-1BED-4DC7-89CC-CD534663BB68

Figure 1

Material examined. Holotype: male, slide-mounted. Original label: "Philippines: Polillo Island (Quezon Province): Cave 5, Sitio Puting Bato, Barangay Aluyon, Burdeos, 13.v.2013 CC Lucañas" "UPLBMNH BLA-00220”, "HOLOTYPE / Nocticola gonzalezi Lucañas \& Lit [laser printed on red slide label]"

Paratypes: 1 male, 1 female, 5 nymphs, same locality as holotype but 10.x.2013: (CC Lucañas, UPLBMNH BLA-00221, ๆ (slide); -00222, ð̊; -00223, nymph (slide); -00224a-d, 4 nymphs). "PARATYPE / Nocticola gonzalezi Lucañas \& Lit [laser printed on blue slide label or handwritten on blue label]".

Type locality. Philippines: Polillo Island (Quezon Province): Cave 5, Sitio Puting Bato, Barangay Aluyon, Burdeos, on calcite rubble with insectivorous bat guano.

Diagnosis. Male brachypterous; female apterous. Compound eyes reduced, much smaller in female. Femur Type $\mathrm{C}_{1}$. Tarsi simple, symmetrical. Tergal gland absent (simoni-species group). Accessory hook-like phallomere (L2d) dagger-like.

Roth (1988) noted the difficulty in separating nocticolid genera. Although Chopard (1945, 1966), being unable to differentiate Nocticola from Alluaudellina Chopard, 1932 noted the possibility of the two being synonyms, Nocticola differs from the latter by the absence of styles. Aside from Nocticola, only Cardacus Strand, 1928 lacks style in the 


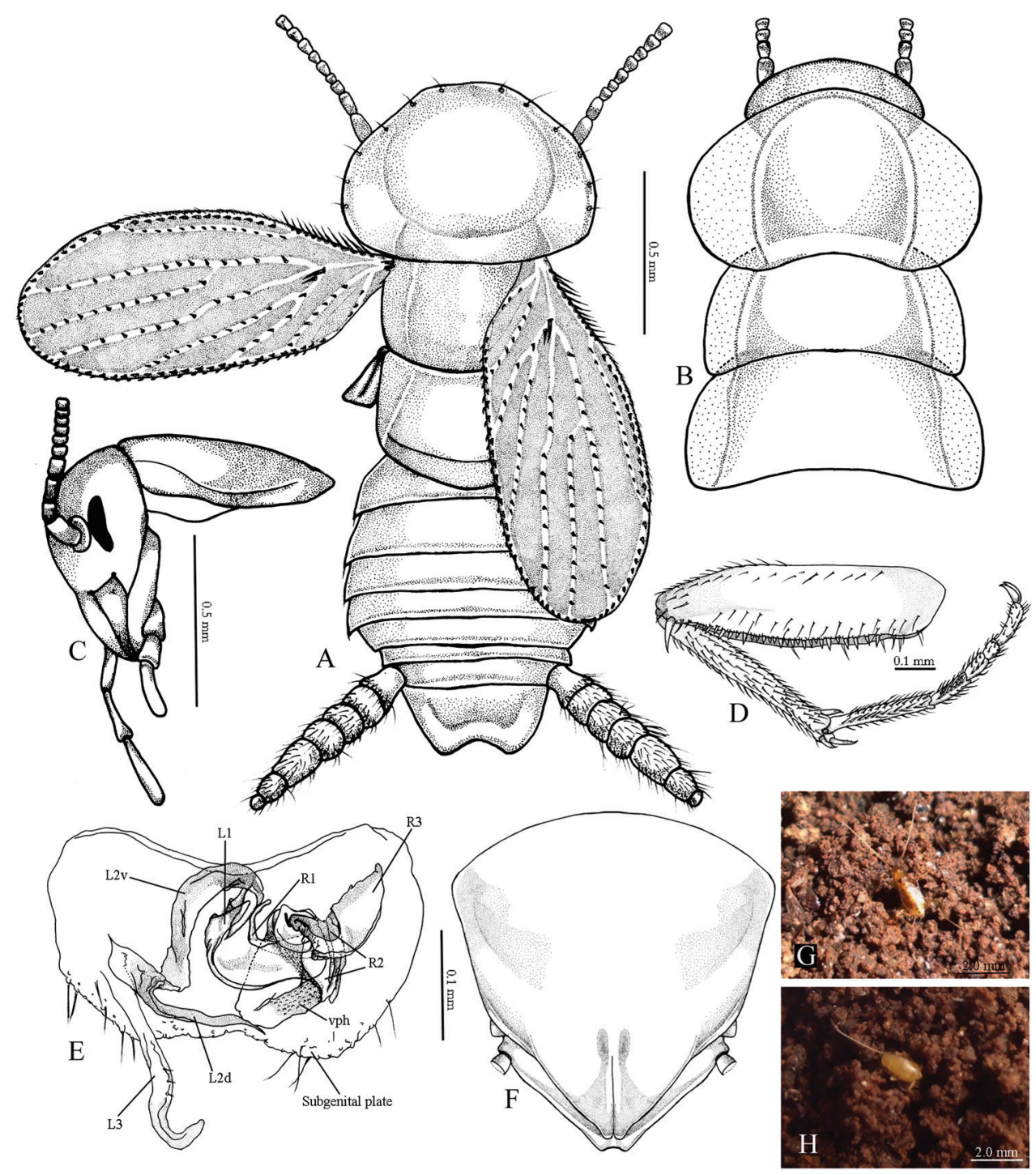

Figure I. Nocticola gonzalezi Lucañas \& Lit, sp. n.: A Adult male B adult female $\mathbf{C}$ male head, lateral aspect D Prothoracic leg E male genitalia: (L1-3: sclerites of left phallomere; L2d: L2 dorsal; L2v: L2 ventral; R1-3: sclerites of right phallomere; vph: ventral phallomere) $\mathbf{F}$ female subgenital plate $\mathbf{G}$ male and $\mathbf{H}$ female habitus.

family. The former is distinguished from the latter by the absence of ocelli and exposed vertex. Following such dichotomy, this new species is placed under Nocticola.

This species can be distinguished from other troglobiotic Nocticola by the presence of an accessory hook-like phallomere which was only reported from two epigean species, $N$. scytala Andersen \& Kjærandsen and N. clavata Andersen \& Kjærandsen from Ghana, West Africa (Andersen and Kjærandsen 1995). 
This species is similar to $N$. simoni and $N$. caeca in terms of coloration but differs in terms of size, $N$. gonzalezi being smaller. Unfortunately, the male genitalia of $N$. simoni and the male of $N$. caeca was not described by Bolivar (1892) and the location of the type specimens are unknown (Paris 1993).

Many Nocticola species are narrow endemics even among caves within a contiguous area (e.g. N. simoni was collected from a cave in San Mateo, Rizal Province and $N$. caeca from nearby Antipolo, also in Rizal Province). Considering this, as well as the morphological characteristics and the isolation of Cave 5 in Puting Bato, Burdeos, Polillo Island, we iterate the distinctness of $N$. gonzalezi.

Description. Size $(\mathrm{mm}): \stackrel{\jmath}{\top}$, TL: $2.36 \pm 0.13 \mathrm{~mm}$; Pn: $0.50 \pm 0.10 \times 0.93 \pm 0.05$ mm; Tg: $1.13 \pm 0.2$. 9 TL: $2.5 \mathrm{~mm}$; Pn: $0.50 \times 0.95 \mathrm{~mm}$.

Male. (Fig. 1A,G). Yellowish brown throughout except for light brown pronotum and tegmina. Vertex of head slightly exposed; eyes reduced but larger than those of female (Fig. 1C); ocelli absent. Pronotum wider than long. Forewing reduced, venation simple indicated by spinules, rounded at apex; hind wing highly reduced, triangular with single vein. Legs very long, forefemur Type $\mathrm{C}_{1}$ (Fig. 1D); mid- and hind femur with apical spines; mid- and hind tibia with several minute spines on outer aspect; hind metatarsi longer than the rest; pulvilli and arolia absent, tarsal claw simple, symmetrical. Abdominal tergal gland absent (simoni-species-group (Roth 1988)). Supra-anal plate symmetrical. Style absent. Genitalia as illustrated (Fig. 1E), genital hook (L3) conspicuous, extending well beyond subgenital plate. Accessory hook-like phallomere (L2d) dagger-like.

Female. (Fig. 1B,H) Larger than male. Opaque yellow throughout except for lateral thoracic margins. Apterous. Supra-anal plate triangular. Subgenital plate broad basally, valvular.

Nymphs. Similar to female. Opaque white. Eyes reduced to 3-4 distinct facets.

Etymology. The species is named after Dr. Juan Carlos T. Gonzalez, the current director of the UPLB-MNH, in recognition of his pioneering efforts toward biodiversity documentation and conservation in the Polillos, a group of islands, east of Luzon and politically a part of Quezon Province.

Distribution. Philippines: Polillo Island.

Ecology. Collected only from a single cave in Burdeos, Polillo Island, Quezon. The cave is deposited with porous calcite rocks and thin guano deposits from periodical roost of insectivorous bats, Hipposideros coronatus (Peters, 1871) and Miniopterus schreibersii (Kuhl, 1817). The site is relatively dry and rocky compared to the damp and sticky clay that is found throughout the rest of the cave, especially during the rainy season. They are quite fast and usually hide among the holes in the calcite rocks. They are found among and probably serve as prey for nymphs of whipspiders (Arachnida: Amblypygi), whipscorpions (Thelyphonida) and adult short-tailed whipscorpion (Schizomida).

Conservation status. Due to the narrow distribution of this species, it is suggested that the species be considered "Vulnerable" and that the cave from which it was collected be protected from further anthropogenic disturbances.

Remarks. Because of its morphological characteristics, this species can be classified as a true cave-dweller or troglobiotic. 


\section{Family Blattidae Stephens, 1829 \\ Genus Periplaneta Burmeister, 1838}

\section{Periplaneta banksi Hanitsch, 1931}

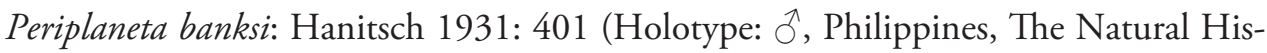
tory Museum (BMNH), London); Bruinjing 1948: 110; Princis 1966: 441; Asahina 1980: 113 .

Material examined. 8 males, 10 females, 3 nymphs: Philippines: Polillo Island (Quezon Province): Bulalon Cave, Poblacion, Burdeos, 23.ii.2013 (IL Lit, Jr/ OL Eusebio/ AR Larona, UPLBMNH BLA-00232-00234, Ō, -00235 †); 25.v.2007 (IL Lit, Jr/ OL Eusebio/ AR Larona, UPLBMNH BLA-00236-00242, ô, -00243-00245, ㅇ, -0024600248, nymphs); 11.vi.2008 (OL Eusebio, UPLBMNH BLA-00528-00531, 우).

Diagnosis. Reddish-brown throughout. Fore femur $A_{2}$ (Fig. 2C). Tegmina well developed (Fig. 2A). Arolia minute. Tarsal claws simple, symmetrical. Male supra-anal plate symmetrical, deeply divided, each lobe rounded and with minute round projection apically (Fig. 2G). Cerci erect, pointed (Fig. 2G). Genital hook (Fig. 2E: L3) angulate, with minute sub-apical process.

Hanitsch (1931) noted the relatively large size of the species compared to other Periplaneta species.

Description. Size $(\mathrm{mm})$ : $\widehat{o} \mathrm{TL}: 45.71 \pm 2.29$; BL: $37.42 \pm 3.69$; Pn: $11.57 \pm 0.79$ $\times 14.86 \pm 1.46$; Tg: $35.71 \pm 2.29$; + TL: $48.5 \pm 2.01$; BL: $41 \pm 2.53$; Pn: $11.6 \pm 0.51$ $\times 15.8 \pm 1.03 ; \mathrm{Tg}: 37.7 \pm 2.41$.

Male. Reddish-brown throughout. Vertex exposed. Ocelli present. Pronotum wider than long, markings indistinct. Tegmina well-developed, extending beyond abdomen. Fore femur $A_{2}$. Pulvilli present on four proximal tarsi. Minute sub-apical spine present on three proximal tarsi. Mid- and hind tibia with several minute spines on outer aspect. Hind basitarsus longer than succeeding tarsi combined. Arolia minute. Tarsal claws simple, symmetrical. Abdominal tergal gland absent. Supraanal plate testaceous, deeply divided, each lobe rounded with minute round projection. Genitalia as illustrated, genital hook angulate, with minute sub-apical process.

Female. Similar to male except that supra-anal plate rounded with deep division. Subgenital plate valvular.

Distribution. Philippines, Taiwan

Ecology. This is the first record of the species inside caves. The species is abundant and most individuals hid among the crevices of the cave walls. They were found from the twilight to the dark zone. Nymphs and mating pairs were often seen, suggesting that the species can complete their life cycle within the cave. Despite that, P. banksi is classified as troglophilic because of the lack of distinct troglobiotic characters and the possibility of the species surviving outside cave conditions.

Both nymphs and adults are possibly preyed upon by whipspiders, Charon sp., and huntsman spiders, Heteropoda sp. 


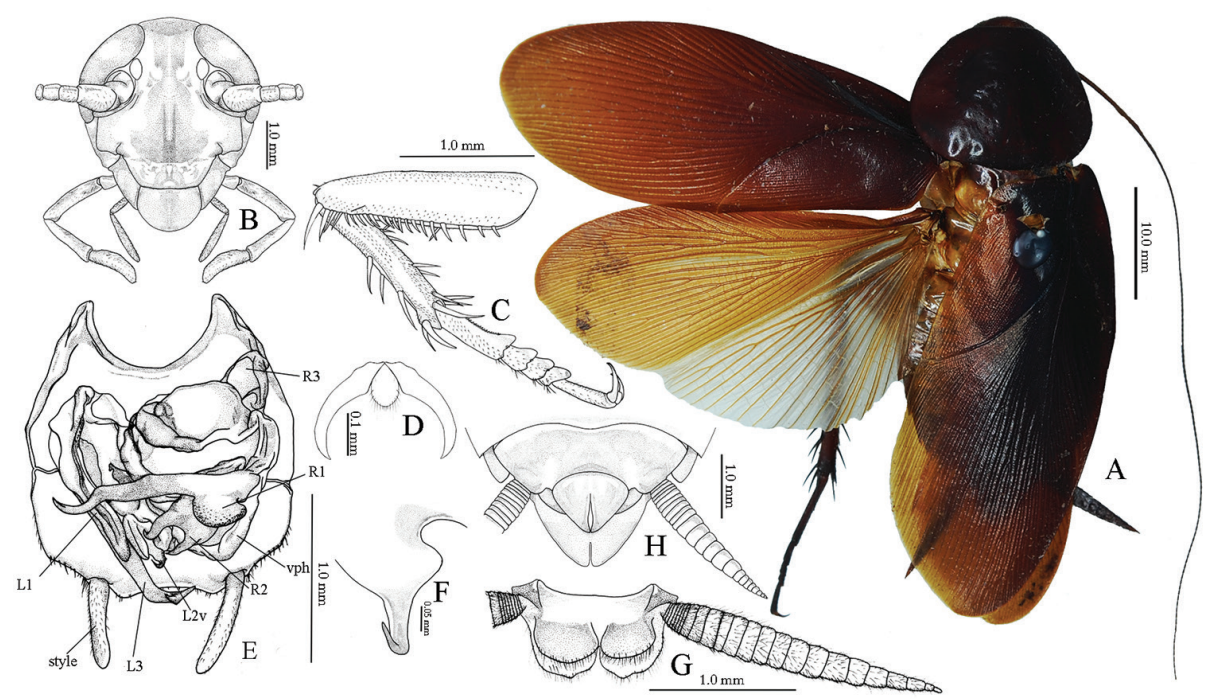

Figure 2. Periplaneta banksi Hanitsch, 1931: A Adult female B head C prothoracic leg D tarsal claws E male genitalia: (L1-3: left phallomere sclerites; L2v: L2 ventral sclerite; R1-3: right phallomere sclerite; vph: ventral phallomere) F L2v close-up $\mathbf{G}$ male supra-anal plate $\mathbf{H}$ female subgenital plate.

Remarks. Hanitsch (1931) described P. banksi from a single female specimen from the Philippines without any further details on its collection locality. Asahinai (1980) later described another female specimen from Taiwan. This is the first time the male of this species is described.

The species resembles $P$. lata (Herbst, 1786), but differs primarily by its larger size. Bruinjing (1948) noted the possibility of the two species being synonyms, but a detailed examination of the male genitalia of $P$. lata is needed to confirm this.

\section{Family Blaberidae Saussure, 1864}

Subfamily Pycnoscelinae McKittrick, 1964

Genus Pycnoscelus Scudder, 1862

\section{Pycnoscelus striatus (Kirby, 1903)}

Figure 3

Leucophaea striata Kirby, 1903: 378 (Lectotype: OA, Batu Cave, Selangor, Malaysia, BMNH, designated by Princis 1956); 1904: 151; Hanitsch 1915: 122, 163; Chopard 1919: 358; Hanitsch 1923: 445, 466.

Pycnoscelus striatus, Chopard 1924: 82; 1929: 367; Hebard 1929: 14; Hanitsch 1929: 266, 287; Hanitsch 1933: 303, 327; Bruijning 1948: 41, 145; Princis 1958: 70; 1964: 274; McClure 1965: 55; McClure et al. 1967: 418; Roth 1973: 251; Roth 1980: 103; 1998: 117; Price 2004: 314; Lucańas et al. 2015: 2. 


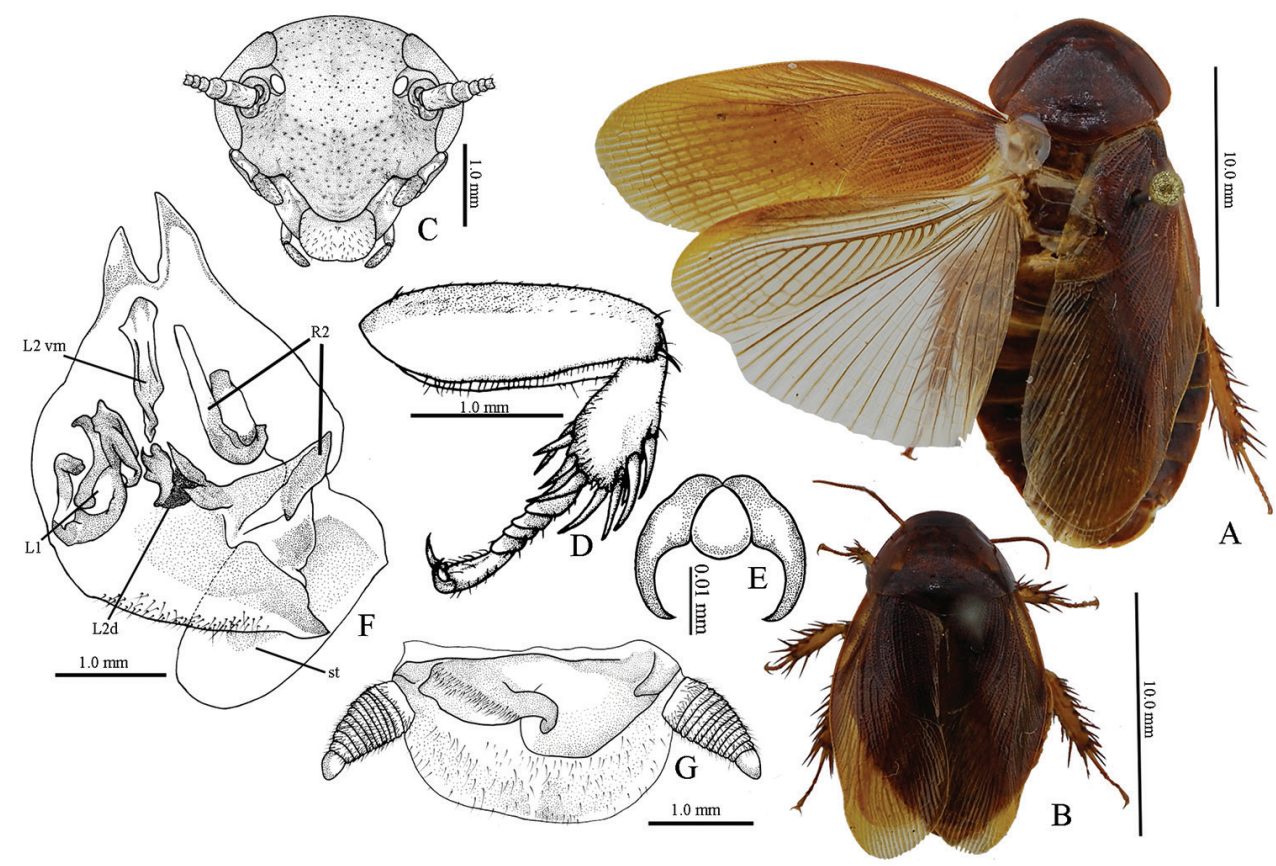

Figure 3. Pycnoscelus striatus (Kirby, 1903): A Adult female B adult male C head D prothoracic leg E tarsal claws $\mathbf{F}$ male genitalia (st: right style; L1-2: left phallomere sclerites; L2d: L2 dorsal; L2vm: L2 ventromedial/ median sclerite; R2: right phallomere sclerite) G male supraanal plate.

Material examined. 22 males, 15 females, 38 nymphs: Philippines: Polillo Island (Quezon Province): Bulalon Cave, Poblacion, Burdeos, v.2010 (JMA Encinares, UPLBMNH BLA-00443-00455 and -00500-00505, ô; -00456-00466, + ; -00467-00497, nymphs), 24-27.ii.2007 (IL Lit, Jr/ OL Eusebio, UPLBMNH BLA-00507-00509, †); Cave 2, Sitio Puting Bato, Barangay Aluyon, Burdeos, 23.ii.2013 (CC Lucañas, UPLBMNH BLA-00517, đ̊; -00518, 9), 23.v.2013 (CC Lucañas, UPLBMNH BLA00524 Õ; -00522-00523, nymphs); Cave 3-4, Sitio Puting Bato, Barangay Aluyon, Burdeos, 23.ii.2013 (CC Lucañas, UPLBMNH BLA-00511, -00515, ổ; -00512, -00516, +; -00513-00514, nymphs); Cave 5, Sitio Puting Bato, Barangay Aluyon, Burdeos, 24.ii.2013 (CC Lucañas, UPLBMNH BLA-00519-00521, nymphs).

Description. Size (mm): đ TL: $14.25 \pm 1.32$; BL: $13.59 \pm 1.15$; Pn: $4.57 \pm 0.42 \times$ $5.91 \pm 0.65$; Tg: $9.68 \pm 1.56$; + TL: $21.39 \pm 1.91$; BL: $17.67 \pm 1.97$; Pn: $5.97 \pm 0.40$ $\times 7.42 \pm 0.43 ;$ Tg: $16.67 \pm 1.91$.

Male. Often less than half the size of females. Vertex exposed. Ocelli present. Pronotum rhomboid, almost as long as wide, reddish-brown, densely punctured. Tegmina variable, reaching slightly beyond abdomen or reaching only up to $7^{\text {th }}$ abdominal tergite. Fore femur $\mathrm{C}_{1}$. Mid- and hind femur unarmed. Pulvilli present on four proximal tarsomeres. Hind metatarsomere slightly longer than succeeding tarsomeres combined. Tarsal claws simple, symmetrical. Arolia minute. Abdominal tergites un- 
specialized. Supraanal plate entire, testaceous. Genitalia as illustrated. Left style absent. Right style ovoid, rounded apically. Genital hook on right side.

Female. Almost similar to males except larger and robust. Wing size highly variable. Subgenital plate entire.

Distribution. Malaysia (Malacca), Indonesia (Sumatra, Kalimantan), Philippines.

Ecology. McClure (1965) noted that P. striatus reaches very high population density, reaching up to $3000 / \mathrm{m}^{2}$ of guano on Batu Caves, Malaysia. Similarly, individuals from Cave 3-4 form dense populations in thick guano from the fruit bat Rousettus amplexicaudatus (Geoffroy, 1810), but are also found in small population on dark zone with thin guano from insectivorous bats. They classified as guanobytes as they burrow beneath layers of guano. They are found together with and may serve as prey to Phlogiellus kwebaburdeos Barrion-Dupo et al., 2014 (Barrion-Dupo et al. 2014, Rasalan et al. 2015), scutigerid centipedes, Scutigera sp. and some whipspiders, Charon sp.

Remarks. Roth (1998) reported a female specimen collected from bat guano in Manhuyod or Negros. Roth temporarily assigned it as Pycnoscelus sp C. due to the absence of a male specimen, but stated that it closely resembles $P$. striatus. The specimen is deposited in the Zoological Institute, Department of Systematics, Lund, Sweden. Several specimens collected from Burdeos have the same interocular width as Pycnoscelus sp. C $(2.3 \mathrm{~mm})$, while some fit with P. striatus $(1.5-1.7 \mathrm{~mm})$. Therefore, it is possible that Pycnoscelus sp. C is a variation of P. striatus. Additional specimens, particularly from the same collection locality of Pycnoscelus sp. C, are needed to confirm this.

The foregoing description of the right style (i.e. rounded apically) differs from that of Roth (1998), which he illustrated as acute apically.

\section{Pycnoscelus sp. D}

Figure 4A

Material examined. 3 females: Philippines; Polillo Island (Quezon Province): Cave 2, Sitio Puting Bato, Barangay Aluyon, Burdeos, 23.v.2013 (CC Lucañas, UPLBMNH BLA-00525-00526), v.2010 (JMA Encinares, UPLBMNH BLA-00527).

Description. Size $(\mathrm{mm}):$ T TL: $21.5 \pm 0.71$; BL: $18.5 \pm 0.71$; $\mathrm{Pn}: 6.5 \pm 0.71 \times 8.5$ \pm 0.71 ; Tg: $17.5 \pm 0.71$.

Male: Unknown

Female: Body generally convex. Vertex concealed. Ocelli present. Pronotum medially wider than long, black throughout except for yellow anterolateral markings, minutely punctate. Tegmina well-developed extending beyond abdomen, hyaline black-brown. Fore femur $\mathrm{C}_{1}$. Hind basitarsus longer than succeeding tarsal segments combined. Pulvilli present on four proximal tarsomeres. Arolium large. Tarsal claws symmetrical. Abdomen medially brown, darkening distally.

Ecology. The species was collected on thick guano piles of mix bat populations in Cave 2. In contrast with $P$. striatus, the species was present only on the top layer of the guano and does not burrow much even if disturbed. 

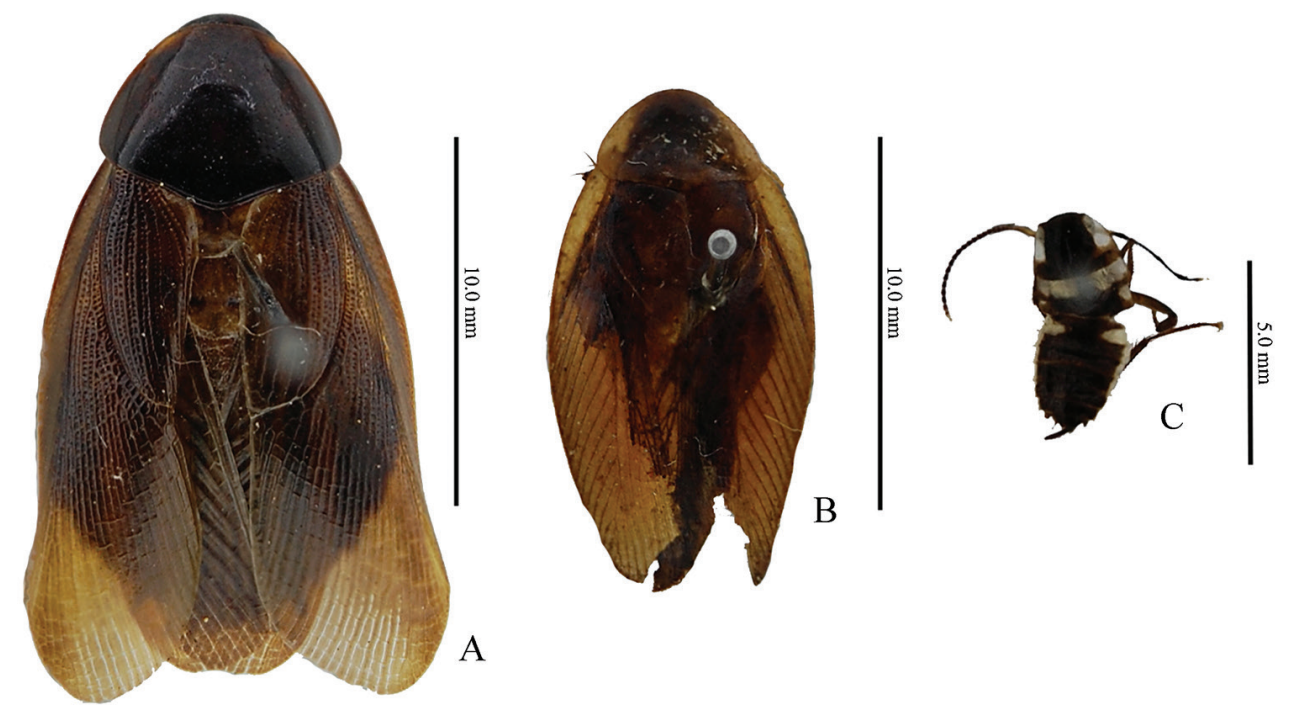

Figure 4. Other cave cockroaches from Polillo Island, Quezon: A Blaberidae: Pycnoscelus sp. D adult female B Ectobiidae: Shelfordina sp., adult female C Hemithyrsocera sp., early instar nymph.

Remarks. This species or form is closely similar to $P$. striatus and may prove to be only a variation. For now, it is treated separately because of its darker coloration, robust abdomen, rather convex body, large arolia and the presence of narrow anterolateral band on its pronotum. The absence of a male specimen hinders further identification.

Roth (1998) described unverified species of Pycnoscelus and temporarily assigned them as spp. A, B and C. In order to avoid confusion, this specimen is temporarily named as Pycnoscelus sp. D.

\section{Family Ectobiidae Brunner von Wattenwyl, 1865}

Subfamily Pseudophyllodromiinae (temporary name)

Genus Shelfordina Hebard, 1929

\section{Shelfordina sp.}

Figure 4B

Material examined. 1 female: Philippines: Polillo Island (Quezon Province): Cave 3-4, Sitio Puting Bato, Barangay Aluyon, Burdeos, 01.iii.2013 (CC Lucañas, UPLBMNH BLA-00533).

Description. Size $(\mathrm{mm})$ : TL: 13.50 ; Pn: $3.00 \times 4.00$; Tg: 10.00 .

Male: Unknown.

Female: Vertex of head slightly exposed. Ocelli minute. Pronotum anteriorly ellipsoid, wider than long, with brown central maculae, anterior and lateral areas hyaline. Fore femur type A2. Mid femora armed with row of spines on outer aspect. Hind 
femora missing from specimen. All tarsomeres with pulvilli, 1-3 spined. Tarsal claws symmetrical with minute dentations. Arolium present. Tegmina well-developed.

Remarks. Accidentals. Since only one female specimen was collected and troglomorphic characters are absent, it can be said that its presence in the cave was accidental.

Roth (1990) described Shelfordina philippensis from Camarines Sur, but later transferred it to the genus Margattea (Roth 1996). Both genera are morphologically similar except for the armature of the fore femora, i.e., type A for Shelfordina and B for Margattea, and the presence of tergal gland on the eighth abdominal segment in males of Margattea.

\section{Subfamily Blattellinae Karny, 1908 \\ Genus Hemithyrsocera Saussure, 1893}

\section{Hemithyrsocera sp.}

Figure 4C

Material examined. 3 nymphs: Philippines: Polillo Island (Quezon Province): Bulalon Cave, Burdeos (v.2010 JMA Encinares, UPLBMNH BLA-00441-00442, nymphs); Cave 3-4 (v.2011 JMA Encinares, UPLBMNH BLA-00532, nymph).

Description. Front femur A2, pulvilli on 4 proximal tarsomeres, tarsal claw simple and symmetric, arolium present. Quite similar to nymphs of $H$. silbergliedi except for the broad lateral white margin of the pronotum and completely black abdomen.

Remarks. Accidentals. This species has been previously recorded only from Bulalon Cave (Lucañas et al. 2015) with only a few early instar nymphs collected inside the cave. Even though $H$. silbergliedi (Roth, 1985) is abundant outside the caves, the slight differences in pronotal coloration and the absence of adult specimens hinders further identification.

\section{Acknowledgements}

The authors would like to express their gratitude to the UPLB-MNH staff for the allowing the first author to tag along during their expeditions and for the use of their laboratory equipment and space during the examination of the specimens; Dr. Aimee Lynn B. Dupo for the use of camera that generated high quality images; IBS Cave Ecology Laboratory, also for the use of space and facilities; Mr. John Mark A. Encinares for the information regarding the specimens from Bulalon and Mapanghe caves; Dr. George W. Beccaloni, Dr. Darren J. Mann and Dr. Christine A. Nalepa for sending references otherwise unavailable to us; and lastly, the local government of Burdeos, Quezon for the permission to conduct the study and the Polillo Ecology Wardens for their support during the fieldwork, without which these expeditions will not be possible. Funding for initial fieldwork in Polillo was received from the UPLB Basic Research Project (No. 88-D66-00) of the second author. 


\section{References}

Andersen T, Kjæransen J (1995) Three new species of Nocticola Bolivar from Ghana, West Africa (Blattaria: Nocticolidae). Journal of African Zoology 109: 377-385.

Asahinai S (1980) Taxonomic notes on non-domiciliary Periplaneta species from the Ryukyus,

Taiwan, Hong Kong and Thailand. Japanese Journal of Sanitary Zoology 31(2): 103-115. doi: $10.7601 / \mathrm{mez} .31 .103$

Barrion-Dupo ALA, Barrion AT, Rasalan JB (2014) A new cave-dwelling mygalomorph spider of the genus Phlogiellus Pocock 1897 (Araneae: Theraphosidae: Selenocosmiinae) from Burdeos, Polillo Island, Quezon, Province, Philippines. Philippine Journal of Systematic Biology 8: 1-15. http://www.philjol.info/philjol/index.php/PJSB/article/view/3326

Bruinjing CFA (1948) Studies on Malayan Blattidae. Zoologische Mededelingen 29: 1-174.

Bolivar I (1892) Voyage de M. E. Simon aux iles Philippines (mars et avril 1890). Etudes sur les Arthropodes cavernicoles de I'ile de Luzon. Orthopteres. Annales de la Societe Entomologique de France 61: 29-34.

Chopard L (1919) Zoological results of a tour in the Far East. Part VI. Les Orthopteres de Birmaine et de la peninsule Malaise. Memoirs of the Asiatic Society of Bengal 6: 339-396. http://www.southasiaarchive.com/Content/sarf.100203/231276/004

Chopard L (1924) Note sur quelques Orthopteres cavernicoles de Sumatra et da Java. Annales de la Societe Entomologique de France 93: 189-192.

Chopard L (1929) XII. Orthoptera and Dermaptera. Journal of the Federated Malay States Museum 14(3-4): 366-371.

Chopard L (1932) Un cas de micropthalmie lice a l'atrophie des ailes chez une blatte cavernicole. Societe de entomologique de France., Livre du Centenaire, Paris, 486-496

Chopard L (1936) Biospeleologica. LXIII. Orthopteres et Dermapteres. Archives de Zoologie experimentale et generale 78: 195-214.

Chopard L (1945) Note sur quelques Orthopteres cavernicoles de Madagascar. Revue Francaise d'Entomologie 12: 146-155.

Chopard L (1966) Une espece nouvelle de Nocticola provenant d'une grotte du Transvaal (Dictyopteres, Nocticolidae). Bulletin de la Societe entomologique de France 71: 307-310.

Encinares JMA, Lit IL Jr (2014) Evaluation of leaf litter baits for sampling insects in Bulalon Cave, Burdeos, Polillo Island, Quezon province, Philippines. Philippine Entomologist 28(1): 76-89. https://journals.uplb.edu.ph/index.php/TPE/article/view/1195

Hanitsch R (1915) Malayan Blattidae. Journal of the Straits Branch of the Royal Asiatic Society 69: $17-178$.

Hanitsch R (1923) Malayan Blattidae part 2. Journal of the Malayan Branch of the Royal Asiatic Society 1: 393-480.

Hanitsch R (1929) Fauna Sumatrensis (Beitrag no. 63), Blattidae. Tijdschrift voor Entomologie 72: 263-302.

Hanitsch R (1931) On a collection of Malayan Blattidae from the British Museum (Natural History). The Annals and Magazine of Natural History 10(7): 385-408. doi: 10.1080/00222933108673325 
Hanitsch R (1933) XXI. The Blattidae of Mt. Kinabalu, British North Borneo. Journal of the Federated Malay States Museum 1: 1-44

Hebard M (1929) Studies in Malayan Blattidae (Orthoptera). Proceedings of the Natural Academy of Science, Philadelphia 81: 1-109.

Juberthie C (2000) The diversity of the karstic and pseudokarstic hypogean habitats in the world. In: Wilkens H, Culver DC, Humphreys WF (Eds) Ecosystems of the World (Vol. 30: Subterranean Ecosystems). Elsevier, Amsterdam, 17-39.

Kirby WF (1903) Notes on Blattidae, with descriptions of new genera and species in the collection of the British Museum, South Kennigton. The Annals and Magazine of Natural History 7(7): 404-415. doi: 10.1080/00222930308678790

Kirby WF (1904) A synonymic catalogue of Orthoptera, vol, I, Orthoptera Euplexoptera Cursoria et Gressoria (Forficulidae, Hemimeridae, Blattidae, Mantidae, Phasmidae. Taylor and Francis, London, 501 pp.

Klass K-D (1997) The external male genitalia and the phylogeny of Blattaria and Mantodea. Bonner Zoologische Monographien 42: 1-341.

Lucañas CC, Encinares JMA, Lit IL Jr (2015) Addenda and corrigenda to the litter-baited cockroach fauna of Bulalon Cave, Burdeos, Polillo Island, Quezon, Philippines. UPLB Museum Publications in Natural History 4: 62-66 https://www.journals.uplb.edu.ph/index.php/MPNH/article/download/1401/1274

Macud AM, Nuñeza OM (2014) Diversity of cave macro-invertebrates in Mighty cave, Tagoloan, Lanao del Norte, Philippines. Journal of Biodiversity and Environmental Sciences 5(3): 276 386. http://www.innspub.net/wp-content/uploads/2014/09/JBES-Vol5No3-p376-386.pdf Mag-usara VRP, Nuńeza OM (2014) Diversity and relative abundance of cockroaches in cave habitats of Siargao Island, Surigao del Norte, Philippines. ELBA Bioflux 6(2): 72-79. http://www.elba.bioflux.com.ro/docs/2014.72-79.pdf

McClure HE (1965) Microcosms of the Batu Caves. Malayan Nature Journal 19: 65-74.

McClure HE, Lim B, Winn SE (1967) Fauna of the Dark Cave, Batu Caves, Kuala Lumpur, Malaysia. Pacific Insects 9(3): 399-428

Paris M (1993) Catalogo de tipos de Ortopteroides (Insecta) de Ignacio Bolivar, I: Blattaria, Mantodea, Phasmatodea y Orthoptera (Stenopelmatoidae, Rhapidophoroidea, Tettigonoidea, Grylloidea, Tetrigoidea). Eos 69: 143-264.

Price L (2004) An introduction to some cave fauna of Malaysia and Thailand. Acta carsologica 33(1): 311-317.

Princis K (1958) Revision der Walkerschen und Kirbyschen Blattarientypen im British Museum of Natural History. Opuscula Entomologia 23: 59-75

Princis K (1964) Pt. 6 Blattariae: Subordo Blaberoidea, Families Panchloridae, Gynopeltidae, Derocalymmidae, Perisphaeriidae, Pycnoscelidae. In: Beier M (Ed.) Orthopterum Catalogus. W. Junk, Gravenhage, 174-281.

Princis K (1966) Pt. 8 Blattariae: Suborbo Blattoidea. Fam.: Blattidae, Nocticolidae. In: Beier M (Ed.) Orthopterum Catalogus. W. Junk, Gravenhage, 402-614.

Rasalan JB, Barrion-Dupo ALA, Bicaldo PRD, Sotto MP (2015) Spider assemblages of Puting Bato Cave 3-4 and surrounding karst forest environs, with additional notes on the cave- 
dwelling nature of Phlogiellus kwebaburdeos. UPLB Museum Publications in Natural History 4: 18-25. https://www.journals.uplb.edu.ph/index.php/MPNH/article/view/1348/1241

Roth LM (1973) The male genitalia of Blattaria X. Blaberidae. Pycnoscelus, Stilpnoblatta, Proscratea (Pycnoscelinae) and Diploptera (Diplopterinae). Psyche 80: 249-264. doi: $10.1155 / 1973 / 32467$

Roth LM (1980) Cave-dwelling cockroaches from Sarawak, with one new species. Systematic Entomology 5: 97-104. doi: 10.1111/j.1365-3113.1980.tb00402.x

Roth LM (1985) A revision of the cockroach genus Parasymploce (Dictyoptera: Blattaria: Blattellidae). Journal of Natural History 19: 431-532.

Roth LM (1988) Some cavernicolous and epigean cockroaches with six new species, and a discussion of the Nocticolidae (Dictyoptera: Blattaria). Revue Suisse Zoologie 95(1): 297 321. doi: 10.5962/bhl.part.79654

Roth LM (1990) Revisionary studies on Blattellidae (Blattaria) from the Indo-Australian region. Memoirs of the Queensland Museum 28(2): 597-663.

Roth LM (1996) Cockroaches from Seychelles Island (Dictyoptera: Blattodea). Journal of African Zoology 110: 97-128.

Roth LM (1998) The cockroach genus Pycnoscelus Scudder, with a description of Pycnoscelus femapterus, sp. nov. (Blattaria: Blaberidae: Pycnoscelinae). Oriental Insects 32(1): 93-130. doi: 10.1080/00305316.1998.10433770

Roth LM (2003) Systematics and phylogeny of cockroaches (Dictyoptera: Blattaria). Oriental Insects 37(1): 1-186. doi: 10.1080/00305316.2003.10417344

Roth LM, Willis ER (1960) The biotic associations of cockroaches. Smithsonian Miscellaneous Collections 141: 1-470. doi: 10.1002/jps.2600500438

Sobrepena JMM, Nuñeza OM (2014) Cave macro-invertebrates of Wao, Lanao del Sur, Philippines. Journal of Biodiversity and Environmental Sciences 5(6): 107-121. http://www. innspub.net/wp-content/uploads/2014/12/JBES-Vol5No6-p107-121.pdf

Strand E (1928) Miscellanea nomenclatoria zoological et Paleontologica. Archiv fur Naturgeschichte. Abteilung 92(8): 30-75. 